\title{
Shell of abalone Haliotis diversicolor supertexta can eliminate waterborne zinc biokinetically
}

\author{
Chung-Min Liao ${ }^{\text {a,* }}$, Kuo-Liang Chang ${ }^{a}$, Bo-Ching Chen ${ }^{a}$, Yun-Hua Chou ${ }^{a}$, \\ Ming-Chao Lin ${ }^{b}$ \\ ${ }^{a}$ Department of Bioenvironmental Systems Engineering, National Taiwan University, Taipei 10617, Taiwan, ROC \\ ${ }^{\mathrm{b}}$ Life Science Division, General Education Center, Nanhua University, Chyayi, Taiwan, ROC \\ Received 1 October 2002; received in revised form 24 June 2003; accepted 24 June 2003
}

\begin{abstract}
Dietary and nondietary accumulation of waterborne zinc $(\mathrm{Zn})$ by shell of abalone Haliotis diversicolor supertexta was studied to determine if abalone shell can accumulate and eliminate $\mathrm{Zn}$ biokinetically. Shell of $H$. diversicolor supertexta rapidly accumulated $\mathrm{Zn}$ at microgram per gram concentrations during a 7-d uptake period for dietary and nondietary exposure to $1 \mu \mathrm{g} \mathrm{ml}{ }^{-1} \mathrm{Zn}$ seawater. Depuration half-lives were 7.22 and $15.40 \mathrm{~d}$ for dietary and nondietary exposure, respectively. The uptake rate constants were 5.12 and $4.84 \mathrm{ml} \mathrm{g}^{-1} \mathrm{~d}^{-1}$, respectively, for dietary and nondietary exposure. The depuration rate constants were 0.048 and $0.10 \mathrm{~d}^{-1}$, respectively for dietary and nondietary exposure. Results from this study showed that the shell of $H$. diversicolor supertexta accumulated $\mathrm{Zn}$ and that it reflected the composition of the seawater in which the abalone lived. This suggested that the shell of $H$. diversicolor supertexta can be used as a bioindicator or can act as a receptor to biokinetically eliminate heavy metals from aquatic food webs.
\end{abstract}

(C) 2003 Elsevier Ltd. All rights reserved.

Keywords: Abalone; Shell; Bioaccumulation; Elimination; Zinc; Haliotis diversicolor supertexta

\section{Introduction}

The accumulations of heavy metal in some marine organisms, such as mollusks and algae, have been suggested as indicators of heavy metal contamination in aquatic ecosystem (Zatta et al., 1992; Karez et al., 1994; Walsh et al., 1995; Han et al., 1997). Many mollusks and algae have wide distributions, extensive populations, sedentary nature and the ability to accumulate contaminants. Monitoring those bioaccumulators for heavy metals is useful as an ideal contamination index in aquatic ecosystems (Burdin and Bird, 1994; Walsh et al., 1994; Uno et al., 1997).

Abalone are common gastropod mollusks that inhabit the coastal reefs in tropical and subtropical areas (Hahn, 1989). The herbivorous gastropod, Haliotis diversicolor supertexta, is the most abundant abalone species in Taiwan. The aquaculture of $H$. diversicolor

\footnotetext{
${ }^{*}$ Corresponding author. Tel.: +886-2-2363-4512; fax: +886-2-23626433.

E-mail address: cmliao@ccms.ntu.edu.tw (C.-M. Liao).
}

supertexta is one of the important aquatic products in Taiwan (Chen, 1984, 1989). H. diversicolor supertexta prefers red algae, Gracilaria spp., which yield the best growth of the abalone (Chen, 1989; Singhagraiwan and Doi, 1993). Because of economic considerations, the seaweed Gracilaria tenuistipitata var. liui has been selected to be the major forage for culturing $H$. diversicolor supertexta.

The accumulation of heavy metals in mollusks has been mainly studied from the content of soft tissues (Lautie et al., 1988). Although Bertine and Goldberg (1972) and Walsh et al. (1995) noted that heavy metals could be accumulated in soft tissue and calcareous shells of mollusks, yet the biokinetic characteristics of the shell is poorly known. Chen (1989) reported that the shell coloration of $H$. diversicolor supertexta differed according to the algae consumed: it was green after consuming Chlorophyceae and brown after consuming Rhodophyceae. It seems conceivable that this abalone utilizes the deposition process of new shell material to relocate bioaccumulated recalcitrant chemicals from the metabolically active soft tissues to the relatively inert shell 


\section{Nomenclature}

BCF bioconcentration factor

$C_{\mathrm{s}} \quad$ zinc concentration in abalone shell

$C_{\mathrm{w}} \quad$ dissolved zinc concentration in water

$F \quad$ the critical value tests for homogeneity

$\mathrm{LT}_{50}$ median tolerant time

SE standard error from the mean

$T \quad$ the time when depuration begins $k_{1} \quad$ uptake rate constant for zinc of abalone shell

$k_{2} \quad$ depuration rate constant for zinc of abalone shell

$n \quad$ sample size

$p \quad$ the probability tests for homogeneity

$r^{2} \quad$ coefficient of determination

$t_{1 / 2} \quad$ chemical half-life material. Karez et al. (1994) indicated that there was a relative lack of information for contaminated regions in tropical and subtropical areas regarding the ability of abalone shell to accumulate heavy metals through nondietary and dietary processes in aquatic environments.

An ideal bioindicator should be sedentary, abundant and exhibit longevity. It should be also easy to collect, able to accumulate pollutants and provide sufficient tissue for contaminant analysis. $H$. diversicolor supertexta meets all of these conditions. Therefore, abalone shell can be considered as an ideal biomaterial for environmental monitoring. Most of $H$. diversicolor supertexta are used for seafood in Taiwan restaurants. The shells of $H$. diversicolor supertexta can be obtained at minimal cost from processing wastes. Belcher et al. (1998) indicated that mollusk shell was a microlaminate composite of mineral and biopolymers with exceptional regularity, and with a strength far exceeding that of the crystals themselves in that the calcium carbonate inorganic phase of the shell contributes $98 \%$ of the shell mass. For example, the shell of Haliotis rufescens, the red abalone, is composed of two different polymorphs of calcium carbonate, calcite and aragonite (Belcher et al., 1996).

Zinc $(\mathrm{Zn})$ is an essential micronutrient found at high levels in the algae and in the tissues of fish/shellfish (Hogstrand et al., 1998; Genter and Lehman, 2000). If waterborne $\mathrm{Zn}$ levels are elevated, however, toxicity can occur and have severe effects on the health of $H$. diversicolor supertexta, which will reduce market prices and cause closure of abalone farms. Previous investigations indicated that $\mathrm{Zn}$ was detected in many rivers and that maximum $\mathrm{Zn}$ concentrations in contaminated aquacultural waters were reported to range from 60 to $300 \mu \mathrm{g}^{-1}$ in different areas of Taiwan (Lee et al., 1996). At these levels, $\mathrm{Zn}$ specifically disrupts calcium uptake by the gills of fish (Hogstrand et al., 1996; Galvez et al., 1998), leading to hypocalcemia, which may end with the death of the fish within a few days, depending on the $\mathrm{Zn}$ concentration.

This paper details a study to examine if shell of $H$. diversicolor supertexta exposed to waterborne $\mathrm{Zn}$ from dietary and nondietary routes via the alga $G$. tenuistipitata var. liui and ambient water, respectively, can accumulate and eliminate $\mathrm{Zn}$ biokinetically in a controlled environment. To our knowledge, this study is the first to examine experimentally both the uptake and elimination of $\mathrm{Zn}$ in the shell of $H$. diversicolor supertexta.

\section{Methods}

\subsection{Experimental setup}

Viable $H$. diversicolor supertexta and $G$. tenuistipitata var. liui were collected for the laboratory exposure experiments from Toucheng located in northern Taiwan, because this was the most $\mathrm{Zn}$-contaminated area in Taiwan (Chen, 1989). The abalone and algal samples initially were washed in seawater to remove epiphytes and kept at $4{ }^{\circ} \mathrm{C}$ during transfer to the laboratory. Abalone with average shell length of $4.03 \pm 0.78 \mathrm{~cm}$ were selected for the experiments. The algal samples selected were mature, whole and healthy. A total of 200 abalone were transferred into four aquatic tanks of approximately 541 , containing 501 of artificial seawater. In order to imitate the environment of the abalone farms, the abalone were held in baskets. Each tank contained 10 baskets. Four abalone per basket were used for analysis. To be sure that at least four abalone would be alive at the end of the experiment, we put one extra abalone in each basket. Dissolved oxygen was maintained near saturation by aeration throughout the experiment. The temperature and salinity were maintained at $25 \pm 1.5{ }^{\circ} \mathrm{C}$ and $35 \%$ under constant illumination (Yang and Ting, 1986). The $\mathrm{pH}$ value remained fairly constant during the experiment $(7.75 \pm 0.24)$. The abalone were fed daily with $G$. tenuistipitata var. liui. The average $\mathrm{Zn}$ concentration in $G$. tenuistipitata var. liui obtained from Toucheng abalone farm was measured to be $91.04 \pm 33.10 \mu \mathrm{gg}^{-1}$ (mean $\pm \mathrm{SE}, n=9$ ). The abalone were acclimatized for two weeks before they were exposed to $\mathrm{Zn}$.

In two tanks, $\mathrm{Zn}\left(\mathrm{ZnCl}_{2}\right)$ was added to the seawater. In one tank the abalone were fed with algae, and in the other tank, the abalone were kept without food. The $\mathrm{Zn}$ level was determined by a preliminary experiment exposing abalone to different $\mathrm{Zn}$ concentrations $(0.25,0.5$, $1,2,4$, and $6 \mathrm{ppm})$. The tolerance $\left(\mathrm{LT}_{50}\right)$ of abalone 
at $\leqslant 1 \mathrm{ppm} \mathrm{Zn}$ was longer than 21 days. Therefore, the abalone were exposed to $1 \mu \mathrm{g} \mathrm{ml}^{-1} \mathrm{Zn}$ for 7 days in this experiment. The abalone were reared in the contaminated environment for 7 days uptake, then transferred to clean seawater and reared for 7 days of depuration. To examine if starvation affects $\mathrm{Zn}$ depuration in abalone shell, the same procedure with abalone was followed over 14 days using the other two tanks, but without $\mathrm{Zn}$ in the seawater.

Abalone and water samples were collected at day 0,1 , 2,4 , and 7 , starting from the day that those organisms were exposed to the contaminated seawater and from the day the organisms were transferred to clean seawater. Each time one basket was taken along with 500 $\mathrm{ml}$ water out of each tank. From this basket four abalone were collected. Because preliminary observations showed that $H$. diversicolor supertexta only feeds at night, and has an empty gut in the evening, we collected the abalone at night to make sure the contents of gut would not influence the results. The experiments in the four tanks, described above, were repeated again. The water samples were fixed with $5 \mathrm{ml} 1 \mathrm{~N} \mathrm{HNO}_{3}$, and the samples of abalone were stored in the dark at $-20{ }^{\circ} \mathrm{C}$ until they were analyzed.

\subsection{Chemical analysis}

The abalone shells were freeze-dried overnight, and then ground into a fine powder in a grinder (Tai-Hsiang S36-89). A $500 \mathrm{mg}$ portion of the ground samples was digested in $10 \mathrm{ml}$ of $65 \%$ concentrated $\mathrm{HNO}_{3}$ overnight at room temperature. The resulting solution was evaporated and redissolved in $0.1 \mathrm{~N} \mathrm{HCl}$. A Perkins-Elmer model 5100PC atomic absorption flame spectrophotometer (Perkins-Elmer, Shelton, Connecticut, USA) equipped with an HGA-300 graphite furnace atomizer was used to analyze $\mathrm{Zn}$. Analytical quality control was achieved by digesting and analyzing identical amounts of rehydrated $\left(90 \% \mathrm{H}_{2} \mathrm{O}\right)$ standard reference materials (DORM-2, Dogfish Liver-2-organic matrix, NRCCNRC, Canada). Recovery rates ranged from $95 \%$ to $97 \%$ and the levels of detection were $0.5 \mu \mathrm{g} \mathrm{Zn} / \mathrm{g}$ shell and $5 \mu \mathrm{g} \mathrm{Zn/1} \mathrm{water.}$

\subsection{Data analysis}

Uptake and depuration rate constants were determined by fitting concentration data to the integrated form of the kinetic rate equation for constant dietary/ nondietary $\mathrm{Zn}$ exposure, using iterative nonlinear regression,

$C_{\mathrm{s}}(t)=C_{\mathrm{s}}(t=0)+C_{\mathrm{w}} \frac{k_{1}}{k_{2}}\left(1-\mathrm{e}^{-k_{2} t}\right)$,

where $C_{\mathrm{s}}$ is the $\mathrm{Zn}$ concentration in abalone shell $\left(\mu \mathrm{g} \mathrm{g}^{-1}\right), C_{\mathrm{w}}$, the dissolved $\mathrm{Zn}$ concentration in water $\left(\mu \mathrm{g} \mathrm{ml}^{-1}\right), k_{1}$, the uptake rate constant for $\mathrm{Zn}$ of shell $\left(\mathrm{ml} \mathrm{g}^{-1} \mathrm{~d}^{-1}\right)$, and $k_{2}$, the depuration rate constant for $\mathrm{Zn}$ of shell $\left(\mathrm{d}^{-1}\right)$. The bioconcentration factor $(\mathrm{BCF})$ is calculated from the equation $\mathrm{BCF}=k_{1} / k_{2}$.

As the first-order one-compartment model assumes that $k_{2}$ is not a function of $\mathrm{Zn}$ concentration in shell, $k_{2}$ is often determined by depurating contaminated organisms in uncontaminated water and determining $k_{2}$ directly in that test organism. Therefore, after the abalone are transferred to clean water and diet tank, respectively, the depuration rate constant $\left(k_{2}\right)$ can be calculated by the linear regression of log-transformed shell $\mathrm{Zn}$ concentrations on depuration time (days) as $\ln C_{\mathrm{s}}(t)=\ln C_{\mathrm{s}}(t=T)-k_{2} t$ where $T$ is the time when depuration begins. Depuration half-life $\left(t_{1 / 2}\right)$ was calculated as $\ln 2 / k_{2}$. Variances in $k_{2}$ values derived from two methods were tested for homogeneity using an $F$-test. Values were then compared using $t$-test. All curve fittings were performed using the nonlinear regression option of the Statistica ${ }^{\circledR}$ software (StatSoft, Tulsa, OK, USA). Statistica ${ }^{\circledR}$ was also used to calculate the coefficient of determination $\left(r^{2}\right)$ and to perform all statistical comparisons.

\section{Results and discussion}

The nonlinear regression resulting from the best fits of Eq. (1) to uptake and depuration concentration data for dietary and nondietary exposure is shown in Fig. 1. The regression equations to exposure concentration data are: For dietary exposure: (1) uptake phase: $C_{\mathrm{s}}(t)=$ $14.4 \mathrm{e}^{-0.048 t}+C_{\mathrm{w}}(106.58)\left(1-\mathrm{e}^{-0.048 t}\right)\left(r^{2}=0.99\right)$ and (2) depuration phase: $C_{\mathrm{s}}(t)=40.5 / \mathrm{e}^{-0.096 t}\left(r^{2}=0.32\right)$; and for nondietary exposure: (1) uptake phase: $C_{\mathrm{s}}(t)=$ $14.4 \mathrm{e}^{-0.10 t}+C_{\mathrm{w}}(48.36)\left(1-\mathrm{e}^{-0.10 t}\right)\left(r^{2}=0.80\right)$ and $(2)$ depuration phase: $C_{\mathrm{s}}(t)=32.67 / \mathrm{e}^{-0.045 t}\left(r^{2}=0.62\right)$. The experimentally determined biokinetic parameters for the Eq. (1) describing the $\mathrm{Zn}$ bioaccumulation process in the shell of $H$. diversicolor supertexta exposed to $\mathrm{Zn}$ from dietary and nondietary routes are summarized in Table 1. A simple, well-established, one-compartment uptakedepuration model in Eq. (1) was thus fitted by the nonlinear technique to the $14 \mathrm{~d}$ exposure data and the average coefficient of determination $\left(r^{2}\right)$ was 0.68 (Table 1). Estimates of $k_{2}$ were also determined from the depuration phases. All of these regressions were significant $(p<0.05)$, with coefficient of determination values ranging from 0.32 to 0.62 (Table 1).

The BCF of abalone shell in the uptake phase (107.56 $\mathrm{ml} \mathrm{g}^{-1}$ ) was greater than that in the depuration phase $\left(53.33 \mathrm{ml} \mathrm{g}^{-1}\right)$ during dietary exposure, whereas the result was opposite in the nondietary exposure (Table 1). Analysis of variance showed that the uptake rate constant of shell of $H$. diversicolor supertexta in dietary exposure was not different from that of nondietary 

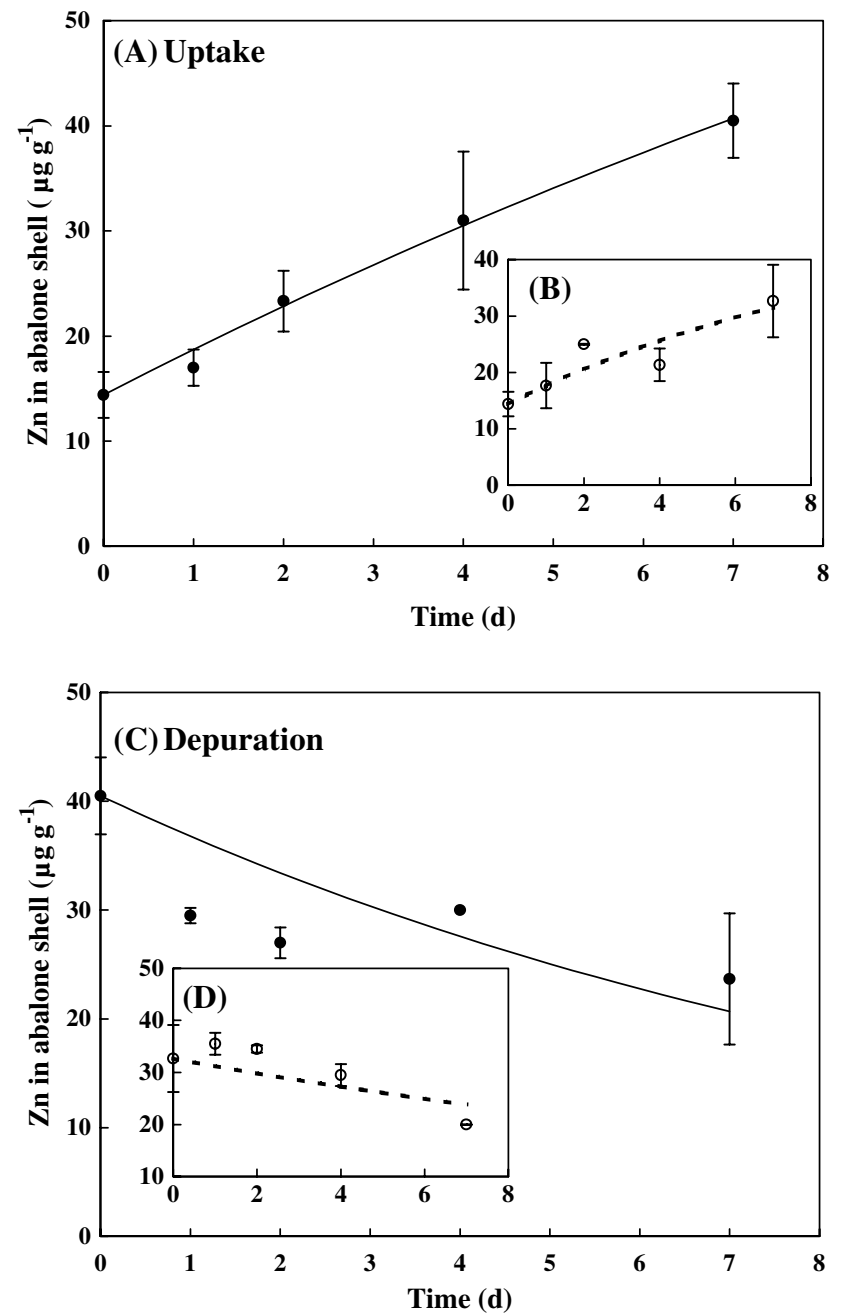

Fig. 1. Uptake ((A) and (B)) and depuration ((C) and (D)) of $\mathrm{Zn}$ by shell of $H$. diversicolor supertexta during a 14-d dietary and nondietary exposure. The measurements are shown with symbols $(\bullet)$ : dietary exposure; $(\mathrm{O})$ : nondietary exposure and the model fittings are shown in lines (-): dietary exposure; (-- -): nondietary exposure. The error bars show one standard error from the mean $(n=4)$.

exposure $(F=0.015, p>0.05)$. There were also no significant differences between dietary and nondietary exposure regarding $\mathrm{BCFs}(F=0.543, p>0.05)$. The results from the experiments without $\mathrm{Zn}$ indicated that $\mathrm{Zn}$ concentrations in abalone shell in dietary exposure were not significantly different from those in nondietary exposure $(F=0.46, p>0.05)$, suggesting that the effect of starvation can be overlooked during the experimental exposure period.

There was some accumulation of $\mathrm{Zn}$ in control abalone shell (14.4 $\mu \mathrm{g} \mathrm{g}^{-1}$ at day 0 in Fig. 1) due to the unavoidable presence of trace amounts at the abalone farm. During dietary exposure, the abalone shell continued to accumulate $\mathrm{Zn}$ in the uptake phase, leading to slower depuration rate $\left(0.048 \mathrm{~d}^{-1}\right)$ compared to that in the depuration phase $\left(0.096 \mathrm{~d}^{-1}\right)$, whereas the absence of algae in nondietary exposure resulted in a higher depuration rate in the uptake phase compared to that in the depuration phase (Table 1). The half-life of the uptake phase in dietary exposure (14.44 d) was larger than that in nondietary exposure $(6.93 \mathrm{~d})$. In the depuration phase, the half-life in nondietary exposure $(15.4 \mathrm{~d})$ was larger than that in dietary exposure (7.22 d).

The results demonstrated that shell of $H$. diversicolor supertexta accumulated considerable amounts of $\mathrm{Zn}$ from seawater. The quantity of heavy metals in shell of mollusks clearly reflects the quantity of the heavy metals in the aquatic environment where mollusks grow (Bertine and Goldberg, 1972; Walsh et al., 1995), suggesting that the shell of $H$. diversicolor supertexta can potentially be a useful bioindicator for the bioaccumulation of $\mathrm{Zn}$ in artificial and natural environments. The percent difference between uptake rate constants in dietary and nondietary exposure was $5.5 \%$, indicating that $\mathrm{Zn}$ in abalone shell was from ambient water and not from the algae. A similar conclusion was reported by AmiardTriquet et al. (1987) where they demonstrated that $\mathrm{Zn}$ levels in algae-grazing mollusks, Gibbula umbillicalis and Littorina littorea, were not different from $\mathrm{Zn}$ levels in a brown alga, Fucus serratus, which was the food species of the mollusks.

Bertine and Goldberg (1972) and Walsh et al. (1995) demonstrated that heavy metals were usually higher in the soft parts than those in the solid shell of clams, mussels and shrimps. The presence of contaminants in

Table 1

Bioaccumulation parameters (mean $\pm 1 \mathrm{SE}$ ) for $\mathrm{Zn}$ calculated from $H$. diversicolor supertexta shell dietary/nondietary exposure data

\begin{tabular}{llllll}
\hline & Dietary & & & Nondietary \\
\cline { 2 - 3 } & Uptake phase & Depuration phase & & Uptake phase & Depuration phase \\
\hline$k_{1}\left(\mathrm{ml} \mathrm{g}^{-1} \mathrm{~d}^{-1}\right)^{\mathrm{a}}$ & $5.12 \pm 1.18$ & & $4.84 \pm 1.51$ & $0.045 \pm 0.02$ \\
$k_{2}\left(\mathrm{~d}^{-1}\right)$ & $0.048 \pm 0.044$ & $0.096 \pm 0.028$ & & $0.10 \pm 0.033$ & 107.56 \\
$\mathrm{BCF}\left(\mathrm{ml} \mathrm{g}^{-1}\right)^{\mathrm{b}}$ & 106.58 & 53.33 & & 48.36 & 15.40 \\
$t_{1 / 2}(\mathrm{~d})^{\mathrm{c}}$ & 14.44 & 7.22 & 6.93 & 0.62 \\
$r^{2 \mathrm{~d}}$ & 0.99 & 0.32 & 0.80 & \\
\hline
\end{tabular}

${ }^{\text {a }}$ Uptake rate constant $\left(k_{1}\right)$ and depuration rate constant $\left(k_{2}\right)$ calculated from Eq. (1), whereas at depuration phase $k_{2}$ calculated using the model ln concentration $=\mathrm{a}+\mathrm{b}$ (time) fitted to depuration concentration data.

${ }^{\mathrm{b}}$ Bioconcentration factor calculated from the equation: $\mathrm{BCF}=k_{1} / k_{2}$.

${ }^{\mathrm{c}}$ Depuration half-life calculated from $t_{1 / 2}=\ln 2 / k_{2}$.

${ }^{\mathrm{d}}$ Coefficient of determination. 
the shell of $H$. diversicolor supertexta may represent an effective and sensitive means to assess contamination in the soft tissue of this organism and to monitor the aquatic ecosystems. Based on these characteristics, the $\mathrm{Zn}$ levels in shell of $H$. diversicolor supertexta indicate the $\mathrm{Zn}$ levels in water. Walsh et al. (1995) suggested that although the $\mathrm{Zn}$ in abalone shell was less than in soft tissue, the shell was still useful as an indicator, yet the amount of $\mathrm{Zn}$ in shell was proportional to the concentration in soft tissue. Results from this study suggest that a certain fraction of the elimination of $\mathrm{Zn}$ may be due to biotransformation and not just a physical diffusion-related elimination process.

\section{Conclusions}

This study has provided biokinetic data for uptake and elimination of $\mathrm{Zn}$ by shell of $H$. diversicolor supertexta, which are essential for developing predictive models of $\mathrm{Zn}$ accumulation in field aquacultural ecosystems. Results from this study imply that abalone shell could act as a toxic waste sink to remove waterborne heavy metals from the metabolically active tissue and therefore effectively eliminate these metals from the food chain in that the relocation of the contaminants to the shell represents an effective detoxification mechanism. The use of abalone shell as a bioindicator may be useful for determining the extent of biotransformation in aquatic food webs, as an essential component of risk assessment of heavy metals.

\section{Acknowledgements}

This study was supported by the National Science Council of Republic of China under Grant NSC 88-2313B-002-070. Sincere thanks also go to abalone farm owners for providing valuable information and for use of their abalone farms, without which this research work would have not been possible. The authors also deeply appreciate the contributive comments by three anonymous referees.

\section{References}

Amiard-Triquet, T.C., Metayer, C., Amiard, B., Berthet, J.C., 1987. In situ and experimental studies of the ecotoxicology of four metals (cadmium, lead, copper, zinc) on algae and grazing gastropod mollusks. Water Air Soil Poll. 34, 11-30.

Belcher, A.M., Hansma, P.K., Stucky, G.D., Morse, D.E., 1998. First steps in harnessing the potential of biomineralization as a route to new high-performance composite materials. Acta Mater. 46, 733736.

Belcher, A.M., Wu, X.H., Christensen, R.J., Hansma, P.K., Stucky, G.D., Morse, D.E., 1996. Control of crystal phase switching and orientation by soluble mollusk-shell proteins. Nature 381, 56-58.
Bertine, K.K., Goldberg, E.D., 1972. Trace elements in clams, mussels, and shrimps. Limnol. Oceanogr. 17, 877-884.

Burdin, K.S., Bird, K.T., 1994. Heavy metal accumulation by carrageenan and agar producing algae. Bot. Marina 37, 467-470.

Chen, H.C., 1984. Studies on the aquaculture of small abalone, Haliotis diversicolor supertexta, in Taiwan. In: Liao, I.C., Hirano, R. (Eds.), Proceeding of ROC-Japan Symposium on Mariculture, vol. 1. Tungkang Marine Laboratory Press, Pintung, Taiwan, pp. 143-159.

Chen, H.C., 1989. Farming the small abalone, Haliotis diversicolor supertexta, in Taiwan. In: Hahn, K.O. (Ed.), Handbook of Culture of Abalone and Other Marine Gastropod. CRC Press, FL, USA, pp. 265-283.

Galvez, F., Webb, N., Hogstrand, C., Wood, C.M., 1998. Zinc binding to the gills of rainbow trout: the effect of long-term exposure to sublethal zinc. J. Fish Biol. 52, 1089-1104.

Genter, R.B., Lehman, R.M., 2000. Metal toxicity inferred from algal population density, heterotrophic substrate use, and fatty acid profile in a small stream. Environ. Toxicol. Chem. 19, 869-878.

Hahn, K.O., 1989. Biotic and abiotic factors affecting the culture of abalone. In: Hahn, K.O. (Ed.), Handbook of Culture of Abalone and Other Marine Gastropod. CRC Press, FL, pp. 113-283.

Han, B.C., Jeng, W.L., Jeng, M.S., Kao, L.T., Meng, P.J., Huang, Y.L., 1997. Rock-shells (Thais clavigera) as an indicator of As, Cu, and $\mathrm{Zn}$ contamination on the Putai coast of the black-foot disease area in Taiwan. Arch. Environ. Contam. Toxicol. 32, 456-461.

Hogstrand, C., Gassman, N.J., Popova, B., Wood, C.M., Walsh, P.J., 1996. The physiology of massive zinc accumulation in the liver of female squirrelfish and its relationship to reproduction. J. Exp. Biol. 199, 2543-2554.

Hogstrand, C., Webb, N., Wood, C.M., 1998. Covariation in regulation of affinity for branchial zinc and calcium uptake in freshwater rainbow trout. J. Exp. Biol. 201, 1809-1815.

Karez, C.S., Magalhaes, V.F., Pfeiffer, W.C., Filho, G.M.A., 1994. Trace-metal accumulation by algae in Sepetiba Bay, Brazil. Environ. Poll. 83, 351-356.

Lautie, N., Carru, A.M., Truchet, M., 1988. Natural bioaccumulation of manganese and iron in the soft tissues of Anodonta cygnea (Molluca, Lamellibranchia, Metabranchia). Malacologia 29, 405417

Lee, C.L., Chen, H.Y., Chung, M.Y., 1996. Use of oyster, Crassostrea gigas, and ambient water to assess metal pollution status of the charting coastal area, Taiwan, after the 1986 green oyster incident. Chemosphere 33, 2505-2532.

Singhagraiwan, T., Doi, M., 1993. Seed Production and Culture of a Tropical Abalone, Haliotis asinine Linne. The Eastern Marine Fisheries Development Center, Thailand, $31 \mathrm{pp}$.

Uno, S., Shiraishi, H., Hatakeyama, H., Otsuki, A., 1997. Uptake and depuration kinetics and BCFs of several pesticides in three species of shellifish (Corbicula leana, Corbicula japonica, and Cipangopludina chinensis): comparison between field and laboratory experiment. Aquat. Toxicol. 39, 23-43.

Walsh, K., Dunstan, R.H., Murdoch, R.N., 1995. Differential bioaccumulation of heavy metals and organopollutants in the soft tissue and shell of the marine gastropod, Austrocochlea constricta. Arch. Environ. Contam. Toxicol. 28, 35-39.

Walsh, K., Dunstan, R.H., Murdoch, R.N., Conroy, B.A., Roberts, T.K., Lake, P., 1994. Bioaccumulation of pollutants and changes in population parameters in the gastropod mollusk, Austrocochlea constricta. Arch. Environ. Contam. Toxicol. 26, 367-373.

Yang, H.S., Ting, Y.Y., 1986. Artificial propagation and culture of abalone (Haliotis diversicolor supertexta Lischke). Bull. Taiwan Fish Res. Inst. 40, 195-201.

Zatta, P., Gobbos, S., Rocco, P., Perazzolo, M., Favarato, M., 1992. Evaluation of heavy metal pollution in the Venetian lagoon by using Mytilus galloprovincialis as biological indicator. Sci. Total Environ. 119, 29-41. 